\begin{abstract}
Assuming that social health status affects the level of human capital, the priority of every modern state should be to ensure that its citizens are provided with adequate health conditions, and thus a sense of health safety. Consequently, state activities aimed at managing safety in the field of health policy should translate into both productivity and working efficiency of society, which in turn should stimulate the economic development of the country. This paper attempts to present selected health safety measures to improve the health of the population with the example of the activities of the EU and public institutions in selected voivodeships implementing the principles of sustainable development and long-term investment in society. In this paper, an analysis of documents relating to direct actions with regard to this issue has been used as a research method. The conducted research shows that the cooperation of EU Member States creates a platform for cooperation on combating health inequalities and basic social determinants of health, the aim of which is to improve the health and quality of life of EU citizens, which in turn should translate into accelerating economic development.
\end{abstract}

KEYWORDS: safety, health security, health policy, economic development, sustainable development

\title{
ANALIZA PORÓWNAWCZA ZARZĄDZANIA BEZPIECZEŃSTWEM ZDROWOTNYM PAŃSTWA A JEGO ROZWÓJ GOSPODARCZY
}

ABSTRAKT: Zakładając, że stan zdrowia społeczeństwa wpływa na wielkość kapitału ludzkiego, priorytetowym założeniem każdego cywilizowanego państwa powinno być zagwarantowanie swoim obywatelom odpowiednich warunków zdrowotnych, a tym samym zapewnienia im poczucia stanu bezpieczeństwa zdrowotnego. W konsekwencji, działania państwa ukierunkowane na zarządzanie bezpieczeństwem w obszarze polityki zdrowotnej powinny przekładać się zarówno na wydajność społeczeństwa, jak i na efektywność jego pracy, co z kolei powinno sprzyjać rozwojowi gospodarczemu państwa. W niniejszym artykule podjęto próbę przedstawienia wybranych działań bezpieczeństwa zdrowotnego w zakresie poprawy stanu zdrowia społeczeństwa na przykładzie działań UE oraz instytucji publicznych wybranych województw realizujących zasady| „,rozwoju zrównoważonego” oraz długoterminowych inwestycji w społeczeństwo. W artykule metodę badawczą stanowi analiza dokumentów odnoszących się do bezpośrednich działań w zakresie omawianego zagadnienia. Z przeprowadzonych badań wynika, że współpraca państw członkowskich UE tworzy płaszczyznę do współpracy nad zwalczaniem nierówności zdrowotnych i podstawowych społecznych determinantów zdrowia, których celem jest poprawa

${ }^{1}$ Częstochowa University of Technology; Poland. 
zdrowia i jakości życia obywateli UE, co z kolei powinno przekładać się na przyśpieszenie rozwoju gospodarczego.

SŁOWA KLUCzowe: bezpieczeństwo, bezpieczeństwo zdrowotne, polityka zdrowotna, rozwój gospodarczy, zrównoważony rozwój

\section{INTRODUCTION}

Both terms 'health' and 'safety' are important categories, often referred to in the contemporary political, social, and scientific discourse. Health is a fundamental value, and the right to health belongs to the basic catalogue of rights; respecting health safety should be supported by effective health policies implemented by the state. The right to health protection of citizens is guaranteed by the European Social Charter of the Council of Europe (Article 11) as of 1991, which emphasized the necessity of eliminating the causes of diseases, helping with counseling and education to improve health, preventing epidemic or endemic diseases, etc. The 2001 World Health Assembly Resolution titled Global health security: epidemic alert and response also warned of phenomena associated with globalization perceived as possible threats to health safety. Particular attention was paid to the possibility of the spread of communicable diseases regardless of national borders as a result of increased population movements or environmental changes resulting from processes such as urbanization or deforestation. They reinforced the belief that adverse events to the health of citizens of one country could develop into an international threat ${ }^{2}$.

Nowadays, health safety is one of the priority spheres of human life and is enumerated among the basic functions of the state, considered a public good, which is a premise for the interventionism of public authorities. This paper assumes that an important determinant of the integrated health safety subsystem in Poland is the health policy. Furthermore, shaping the cohesion of the comprehensive safety of the state depends on the implementation of an appropriate internally coherent health policy, with its aim to strive for the increase of the sense of health safety while maintaining the principles of sustainable social development, which in turn translates into the quality and standard of living of the society and the economic development of the country.

Until the mid-19th century, people were dying in large numbers in various parts of the world as a result of various infectious diseases such as: cholera, the plague and the Spanish flu epidemic, which killed almost 50 million people in 1918-19193. The discoveries made in the nineteenth century by scholars such as Ludwik Pasteur, Józef Lister, and Robert Koch allowed us to prevent the aforementioned diseases. The General Board of Health established in London in 1848 conducted research on the reasons behind the high mortality among the inhabitants of large cities due to cholera. And in 1851, the founding International Sanitary Conference was

\footnotetext{
${ }^{2}$ P.M. Nowicka, J. Kocik, Zewnętrzne zagrożenia bezpieczeństwa zdrowotnego Polski [External Threats to Health Security of Poland], "Studia BAS" 4(56) 2018, pp. 103-121.

${ }^{3}$ R. Paruzel, Światowa Organizacja Zdrowia - bezpieczeństwo zdrowotne świata [World Health Organization - World Health Security], "Logistyka” 201(5), pp. 1207-1208.
} 
held in Paris to exchange information on epidemic diseases and their treatment. The research initiated by the Conference led to the establishment in 1907 of the International Health Organisation [Office international d'Hygiène publique (OIHP)] in Paris, which has become the predecessor of the current World Health Organisation, known as the WHO, being a specialised UN organisation established in 1948 and based in Geneva ${ }^{4}$.

The orderly collective initiatives, aimed to combat outbreaks of infectious diseases that were killing thousands of human beings, resulted in invention of effective vaccines, allowed to carry out preventive vaccinations and to curb emergence of epidemics where they were used. As a consequence, they have also contributed to healthcare activities, which have undoubtedly resulted in the increased importance of health policy.

The contemporary health policy forms an integral part of social policy and constitutes the entirety of public activities undertaken by the state and other entities that are to serve healthcare. These actions are tailored to the needs of healthcare and aim to tackle social inequalities in health and healthcare through the appropriate distribution and use of healthcare resources as well as through increasing access to health services.

Since human life and health are closely related and also need exceptional protection due to their value, which is independent of other legally protected goods, health policy is also increasingly integrated into various European health programmes. Therefore, the recognition of health as a good of particular importance seems to be derived from the recognition of human life as an overarching value. According to the World Health Organisation, the concept of 'health' is defined as a state of complete physical, mental and social well-being, enabling a human being to lead a productive, meaningful and creative life in the social and economic sphere, as well as the ability to play social roles, adapt to and cope with environmental change ${ }^{5}$. However, in order for an individual to achieve this state, cooperation is needed both between individuals and between entire communities, who should be able to specify and meet their aspirations and satisfy basic needs, coping with the challenges of the surrounding reality and changes occurring therein.

Health is also a matter of interest for economic sciences, which consider health as an instrumental value, creating a specific social and economic framework for improving the quality of life. In this regard, the costs of improving quality of life, considered in the health sector, are taken into account in the demographic and economic context. Health policy is determined by: political factors, which show the place occupied by health problems in the sphere of influence of the legislative and executive authorities and in political parties' programmes; economic factors, which are related to the overall economic situation and the unemployment level, as well as demographic and health-related factors resulting from demographic development and earlier

\footnotetext{
${ }^{4}$ N. Davies, Europa - rozprawa historyka z historia [Europe: A History]., trans. E. Tabakowska, Kraków 1999, pp. 624-626.

${ }_{5}^{5}$ L. Frąckiewicz (ed.), Polityka społeczna. Zarys wykładu wybranych problemów [Social Policy. Outline of the Lecture of Selected Problems], Katowice 2002, p. 62.
} 
health policy actions ${ }^{6}$. This paper attempts to present the relationships of health safety and health policy with the economic development of the country. It discusses, inter alia, the selected measures of the health policy carried out within the European Union, as well as actions taken at the national level. As an example of measures taken by public authorities in implementation of the principles of "sustainable development" and long-term investments in society aimed at economic development, activities carried out in two selected voivodships have been analysed. The paper has been written based on the literature on the subject, research articles, international reports, the most recent documents and publications available in the electronic database of the European Union, the OECD, and the documents of the Ministry of Health.

\section{Health Policy and Economic Development of the Country}

The economic development issues have been present in the economic literature for at least several centuries. Researchers have been long wondering what factors and stimulants affect its development and what makes some countries develop faster and others at a slightly slower pace. Economic development is a desirable phenomenon because it is inter alia linked to the development of civilisation, improvement of the standard of living of the society, improvement of the quality of life and, primarily, to the increase of income. Therefore, the "economic development" is understood as the process of transformation of economies with low national income into modern economies. This term describes positive transformations in economies, taking into account not only quantitative but also qualitative aspects.

There is a two-way relationship between health policy and economic development of the state. Therefore, when discussing the relationship between the health policy and the economic growth, special attention should be paid to the issue of health in terms of its impact on the quality and size of human capital. When it comes to individuals, health determines the possibility of their personal development and economic security, and together with relevant education, it constitutes the basis for human capital, determining the economic productivity of an individual. N. Ozturk mentions four arguments for the relationship between individual education and economic development: first, through scientific and technological development, education increases work efficiency and thus production; second, education ensures the development of potential skills of individuals; third, education increases the capacity to adapt to new business opportunities, and fourth, educational institutions ensure that knowledge is passed on to future generations by appropriately qualified staff ${ }^{7}$. According to the World Economic Forum, held in Davos in 2016, there are three channels through which education affects country's economic development. First, education allows to carry out tasks more quickly, thus increasing

\footnotetext{
6 T. Szumlicz, System zabezpieczenia społecznego w zarzadzaniu zdrowiem [Social Security System in Health Management], [in:] W. Korporowicz (ed.), Zdrowie i jego ochrona. Między teoria a praktyka [Health and Its Protection. Between Theory and Practice], Warszawa 2004, p. 59.

${ }^{7}$ N. Ozt"urk, Iktisadi kalkınmada e gitiminrol"u, "Sosyo Ekonomi Dergisi" 1(1), 2005, pp. 27-44.
} 
the collective ability of human capital. Second, education facilitates the transfer of new information, of knowledge about products and technologies created by others. Third, by increasing the creativity of human capital, education boosts the country's own capacity to create new knowledge, products, or technologies

Health is also a determinant of high labour productivity, efficient learning, and physical, emotional and intellectual development of a human being, which in turn contributes to the increase in human activity in the economic, social, professional, etc. dimensions, ultimately affecting the overall level of economic activity of a given society. A.G. Akpolat believes that healthier individuals achieve more effective results in work than those with poor health. Besides, health has a positive impact on economic growth, by improving the quality of work performed and increasing work productivity across the whole economy ${ }^{8}$.

Another factor, closely related to health, that greatly affects economic development is the increase in average life expectancy. In healthier societies, people live longer and their resources are substantially greater thanks to a longer period of making savings. Therefore, adequate health education plays an important role in economic development, which is defined as any combination of experience based on willingness to help individuals and communities improve their health by increasing knowledge or influencing their health knowledge.

In turn, W. Jack and M. Lewis believe that the increase in average life expectancy of adults results in increased investment in own children, which in turn improves the human capital of future generations ${ }^{9}$. The decreasing mortality leads to an increase in the retirement age, and as a result the society's saving rates ensure a high level of investment ${ }^{10}$.

In addition, with a longer perspective of reaping the benefits, people decide to make longterm 'investments' and thus longevity indirectly increases expenditure on e.g. education, construction, etc. Therefore, beside the concepts closely related to the income category, economic growth analyses should also take into account indices that characterise health and average life expectancy.

It should be, however, borne in mind that, on the one hand, health has a favourable effect on economic growth, but on the other hand, the economic consequences of diseases are highly negative for societies. This is because health problems result in a decrease in individual incomes and a reduction in the economic activity of individuals, which has an ultimate negative impact on the condition of the entire economy.

In turn, when discussing the impact of economic development on health policy, it should be emphasised that it determines, to a decisive extent, the health of individuals, as well as the general level of health of the society. The economic development in modern societies is followed by a higher average standard of living. The economic development also contributes to

\footnotetext{
${ }^{8}$ A.G. Akpolat, The Long-Term Impact of Human Capital Investment on GDP: A Panel Cointegrated Regression Analysis, "Economics Research International” 2014, p. 10.

${ }^{9}$ W. Jack, M. Lewis, Health Investments and Economic Growth: Macroeconomic Evidence and Microeconomic Foundations, Policy Research working paper no. WPS 4877, pp. 2-39.

${ }^{10}$ D.N. Weil, Accounting for the effect of health on economic growth, Working Paper 11455, 2005, pp. 1265-1306.
} 
an increase in the population's income, which in turn may be increasingly allocated to health insurance or healthcare financing. At the same time, it allows for wide implementation of an appropriate health policy, within which various programmes are implemented, such as prevention and pro-health education programmes. The economic development should also translate into better access to medical services.

In conclusion, on the one hand, the health status of society is an important factor affecting the quality of social capital, which determines both the productivity of enterprises and the longterm development of economies. On the other hand, a higher level of the country's economic development ensures more resources that may be allocated to the health system, thus enabling better medical care and access to medical services, which in turn translates into the health status of the population and its average life expectancy.

\section{Health Safety in the Area of Health Policy and Economic DEVELOPMENT OF THE COUNTRY: EXAMPLES OF EU ACTIVITIES}

Achieving a higher level of health protection is one of the main objectives of the European Union (EU) in all European policies and activities, in accordance with Article 168 of the Treaty on the Functioning of the European Union (TFEU). In particular, EU health policy aims to improve public health, prevent diseases and threats, and combat major health scourges by promoting research.

The EU is taking a number of health policy actions, including the following: improving public health, preventing and treating diseases, reducing the number of sources of danger to human health or harmonising health strategies between Member States. These actions are carried out in different areas of EU functioning ${ }^{11}$.

In the report "Our Common Future" of the World Commission on Environment and Development of 1987, G. Brudtland introduced and defined the term 'sustainable development' as "development that meets the needs of the present without compromising the ability of future generations to meet their own needs". In 2001, the European Union adopted a strategy for sustainable development, which was subsequently revised in 2006. This strategy formulates recommendations for countries and organisations concerning specific problems to be solved in the implementation of sustainable development (e.g. combating poverty, demographic dynamics, protection of human health, environmental protection, management of the Earth's surface resources, waste management). These documents are the basis for international legal acts, global and regional (cross-border), defining the strategy of sustainable development in a given place (country, region, economic sector, institution). Sustainable development has officially become one of the long-term objectives of the European Union in accordance with Article 3(3) of the Treaty on European Union.

\footnotetext{
${ }^{11}$ M. Bsoul- Kopowska, Strategic goals of the European Union In managing health security, [in:] R. Ulewicz, R.R. Nikolić (ed.), System Safety: Human - Technical - Facility - Environment, Częstochowa 2019, pp.78-84. 
The third Programme for the Union's action in the field of health for the period 20142020 was launched in 2014. The aim of this programme is to foster health in Europe by encouraging cooperation between EU Member States. Private bodies, national and European authorities as well as European and international NGOs are also involved in the implementation of this project. The general objective of the programme is to improve Europeans' health and reduce inequalities by complementing Member States' policies in four areas.

The first area aims to promote good health and prevent diseases through the exchange of information and good practices on how to deal with various risk factors, including smoking, drug and alcohol abuse, unhealthy diet, and sedentary lifestyles. The second area involves the protection of EU citizens from serious cross-border health threats. It should be noted that due to the increase in international travel and trade, citizens are potentially exposed to a wider range of health risks than in the past, requiring a raid and properly coordinated response to emerging threats. The third area, which needs to be complemented, involves the support of innovation and sustainability in EU countries' health systems. The launched programme seeks to help build capacity in the health sector, find optimal ways to make scarce resources go further, and encourage the adoption of innovations in approaches, working practices, and technologies. The fourth and last area of actions, involving the improvement of health policy and thus the increase in the sense of health security among EU citizens, is aimed at improving access to high quality and safe healthcare, which should mean, for example, ensuring that medical expertise is available beyond national borders, by encouraging the creation of networks of centres of expertise across the EU.

With a budget of $€ 446$ million, the programme complements Member States' activities and aims to improve access to high quality, safe healthcare for citizens; to promote health and prevent diseases, as well as to protect citizens from cross-border health threats. Activities to be financed under the programme may include projects on rare diseases, cooperation on health technology assessment, prevention programmes, screening and exchange of good practice.

The support under the programme is available to all EU countries, but also to EU candidate countries, European Economic Area (EEA) countries, and the countries to which the European Neighbourhood Policy (ENP) applies. Funds for programmes implementation take the form of grants, awarded to both public institutions and non-governmental organisations. It is worth noting that the EU co-funding amounts to $60 \%$ of the total cost, and in the case of countries with a low GDP, it can reach up to $80 \%^{12}$. In March 2021, the Regulation of the European Parliament and of the Council was adopted, establishing the Programme of the Union's action in the field of health for the period 2021-2027, which aims, among other things, to improve and promote health in the EU states with the objective of reducing the burden of communicable and non-communicable diseases by supporting health promotion and disease prevention; to reduce

\footnotetext{
${ }^{12}$ Zdrowie na rzecz wzrostu gospodarczego: Wspólnotowy program działań w dziedzinie zdrowia (2014-2020) [Health for Growth: Community Action Program in the Field of Health (2014-2020)], EUR-Lex, https://eurlex.europa.eu/legal-content/PL/TXT/?uri=LEGISSUM\%3A290102_1, (10.10.2021).
} 
health inequalities; to promote healthy lifestyles and access to healthcare; to protect the population of the Union from major cross-border health threats; to strengthen the responsiveness of health systems; to improve the availability and affordability of medicinal products and medical devices; to strengthen health systems by improving their resilience and resource efficiency.

\section{ACTIVITIES OF PUblic INSTITUTIONS FOR THE IMPROVEMENT OF HEALTH OF THE INHABITANTS IN SELECTED VOIVODESHIPS aS AN EXAMPLE OF HEALTh SAFETy MANAGEMENT}

The following chapter has been written on the basis of data derived from the analysis of health needs maps for the whole country and for the selected voivodships. These maps present demographic and epidemiological data, data on the services provided and on the use of staff and equipment, being a basis for forecasts of future needs for health services in individual voivodships and in the country as a whole.

Maps of health needs are drawn up as a result of expectations and indications of the European Commission because the estimation of individual investment needs in the health sector through the creation of the above-mentioned maps is raised by the European Commission in relation to the fulfilment of the so-called ex-ante conditions (i.e. an analysis determining the need for a given implementation) in terms of the possibility to support the healthcare infrastructure from EU funds in the financial perspective 2014-2020. These maps are prepared every three years in cooperation with, inter alia, the National Institute of Public Health, and are updated once a year. The creation of health maps results in more rational funding of healthcare in the region. By comparing these health maps, the supra-regional problems, requiring cooperation of several voivodships, may also be diagnosed.

Pursuant to the Act of 27 August 2004 on healthcare services financed from public funds, the tasks of public authorities in ensuring equal access to healthcare services include in particular: creation of conditions for the functioning of the healthcare system; analysis and assessment of health needs and affecting factors; health promotion and prevention aimed at creating conditions conducive to health; healthcare services financing in the manner and on the principles set out in the above-mentioned $\mathrm{Act}^{13}$.

For the purpose of this paper, Łódź and Lesser Poland Voivodeships were analysed. The analysis related to the priorities of health policy in the examined voivodships and measures taken by public institutions aimed at, inter alia, reducing the inequalities in access to medical services, improvement of medical infrastructure, of access to specialists, improvement of healthcare or promoting health, which in turn is reflected in the improvement of the general health status of the society and, consequently, contributes to the economic development.

\footnotetext{
${ }^{13}$ Miejski Program Ochrony Zdrowia „,Zdrowy Kraków 2019-2021”, Urząd Miasta Krakowa Biuro Ds. Ochrony Zdrowiam Kraków 2018 [Municipal Healthcare Program “Healthy Krakow 2019-2021”, Krakow City, Office for Health Protection, Krakow 2018], https://www.bip.krakow.pl > MPOZ 2019-2021 (11.10.2021).
} 
The following criteria were taken into account: birth rate, life expectancy, total health expenditure, number of physicians, number of hospital beds, and access to hospital care versus incidence and mortality from diseases. Furthermore, the main aim of the study was to present the activities of public institutions to improve the health status of the inhabitants of the voivodeships studied. An attempt was also made to answer the following question: Does the proper management of health policy in the area of health safety determine the improvement of health status and help achieve health and social well-being of the population, which in turn contributes to the economic development of the country?

\section{HEALTh-ORIENTEd MEASURES IN LODZKIE VOIVODSHIP}

The Lodzkie voivodship has a population of over 2.5 million, but there has been a systematic decline in the number of inhabitants since 2002. The natural growth rate is also lower than that for Poland (0.0/1 thousand inhabitants) and is $-3.0 / 1$ thousand inhabitants ${ }^{14}$.)

The average life expectancy for women in the Lodzkie voivodship is 79,8 years and for men $-70,6$ which is the worst result in the country. The number of doctors and hospital beds is 24.8 and 51.2 per 10,000 residents respectively. The phenomenon of population ageing is observed in this voivodship. In 2012, pre-working age people represented $17.1 \%$ of the population, the working age population $-62.9 \%$ and post-working age population $20.0 \%$. In 2016 , there were almost 455,000 people aged 65 and older, representing $18.3 \%$ of the total population compared to $16.4 \%$ for Poland. According to forecasts of the Central Statistical Office (GUS), the percentage of post-working age population will grow - it is assumed that in 2035 people in this group will constitute $29 \%$ of the total population, the pre-working age people $-15 \%$, and the working age people $-57 \%$.

As many as $44 \%$ of Lodzkie voivodship's residents suffer from health problems. Every second person suffers from at least one chronic disease, while the average resident of the region over 65 years of age suffers from three or four chronic diseases and constantly takes from four to six medicines. The most common diseases include: hypertension, ischaemia, arthritis, and diabetes. At least half of the elderly suffer from these diseases. Other common ailments include spinal diseases, neuroses, and depressions.

Based on the data on average life expectancy, lower than in other voivodships, the health condition of Lodzkie voivodship's residents should be considered the worst in the country. Adult mortality is also the highest and infant mortality is high.

The above data show that the highest expenditure on treatment per capita, as well as the highest concentration of doctors and the relatively short waiting time for a visit to a specialist are not reflected in the health condition of inhabitants of this voivodship, which can be

\footnotetext{
${ }^{14}$ Mapa zdrowia Polaków, Strategia polityki zdrowotnej dla województwa łódzkiego na lata 2014-2020. [Health Map of Poles. Health Policy Strategy for the Lodz Voivodship for 2014-2020]. http://www.strategiazdrowia.lodzkie.pl/files/file_16/STRATEGIA-POLITYKI-ZDROWOTNEJ-DLA-WOJEWODZTWALODZKIEGO-NA-LATA-2014-2020.pdf (12.10.2021).
} 
considered the worst in the country. This is also evidenced by the number of disability decisions per 100 thousand people, which is one of the highest in the country ${ }^{15}$. In view of the health problems of residents, the health policy of the local government in the Lodzkie voivodship focuses mainly on setting health priorities and main directions for action in the healthcare system in the voivodship with the aim of improving the quality of and access to medical services, increasing the health safety of residents and strengthening the health of the community through preventive measures. It concerns, in particular, the development of the care system for people with cancer and cardiovascular diseases, as well as the development of long-term, geriatric, palliative, and hospice care system ${ }^{16}$. Within the framework of its health policy, the Lodzkie voivodship also participates in other activities, e.g. of a national nature, whose implementation may bring measurable benefits in terms of meeting the health needs of the residents. As an example, participation in the "Partnership for Transplantation" Programme can be mentioned.

The budget of the Lodzkie voivodship for 2019 assumed the healthcare expenditure of approximately PLN 24 million, which represented $1.4 \%$ of the last year's budget ${ }^{17}$.

The health policy priorities for the region in recent years have been defined in the document entitled: "Voivodship Programme - Health Policy Strategy for the Lodzkie Voivodship for 2006-2013", whose main objective was to "Improve the health condition of residents of the Lodzkie voivodship". The tasks performed under the mentioned Strategy include, inter alia, establishment of an injury centre in the M. Kopernik Voivodship Specialist Hospital in Lodz, establishment of a Centre for the diagnosis and treatment of infectious diseases in the Dr. W. Bieganski Voivodship Specialist Hospital in Lodz, improvement of access to neurological rehabilitation (creation of 9 wards of this type), and the start of work on establishment of a centre for stroke prevention and treatment.

At present, the "Health Policy Strategy for the Lodzkie voivodship for 2014-2020" is being implemented. Based on the diagnosis of the demographic situation, socio-economic trends and forecasts, the Strategy has identified the most important challenges facing the regional policy of the voivodship until 2020. One such challenge is to provide the inhabitants of the region with access to good quality services in the field of: education, health, culture and recreation as well as ICT and technical infrastructure. And in order to improve the health situation of voivodship's residents, it was planned to take actions in the field of health prevention and to develop specialist healthcare services and improve access to basic medical services. Moreover, it was indicated that in the context of demographic changes, it is necessary to develop social assistance and the elderly services sector.

\footnotetext{
${ }^{15}$ Ibidem.

${ }^{16}$ Priorytety dla regionalnej polityki zdrowotnej dla województwa łódzkiego. Aktualizacja[Priorities for the Regional Health Policy for the Lodz Voivodship], https://www.lodzkie.eu/data/other/priorytety_dla_regionalnej_polityki_zdro_1.pdf., (11.10.2021).

17 Łódzkie: czy zdrowie będzie priorytetem samorządu w 2019? Polityka Zdrowotna, [Łódź Voivodeship: Will Health Be a Priority for the Local Government in 2019? Health Policy], https://www.politykazdrowotna.com/40910,lodzkie-czy-zdrowie-bedzie-priorytetem-samorzadu-w-2019, (13.10.2021).
} 


\section{HEALTH-ORIENTED ACTIVITIES IN THE MALOPOLSKIE VOIVODSHIP}

At the end of 2018, the Malopolskie voivodship was inhabited by about 3,401 thousand people. They represented $8.9 \%$ of the total population of Poland. In contrast to the Lodzkie voivodship, the population of the Malopolskie voivodship increased by $0.3 \%$. The natural increase was caused by the predominance of births over deaths and amounted to 5.4 thousand people. The natural increase rate per 1,000 people was also positive and amounted to 1.6.

In terms of gender, the majority, that is, $51.5 \%$ of the population, were women. The trend of the growing median age, and of the growing old age and intergenerational support indicators observed in recent years, continuously confirmed the process of ageing of the population in the Malopolskie voivodship.

Malopolska is a region with the average life expectancy higher than this for the entire country, but the waiting time for specialists and hospital beds is extremely long. The average life expectancy for women is 81,9 years and for men 74 years. The number of doctors and hospital beds is 22.7 and 44 per 10,000 residents respectively.

At the end of 2018, the pre-working age population accounted for $19 \%$ of the total population. At the end of 2018, the working age population decreased by $0.5 \%$ compared to the previous year and currently accounts for $61.0 \%$ of the total population. An increase in the number of the post-working age population, which was $20.0 \%$ in 2018 , was still observed.

Therefore, the following have been considered as the most important health priorities for the Malopolskie voivodship for 2019-2021: 1. Increasing the availability and quality of services in the field of prevention, diagnosis and treatment of cardiovascular diseases, treatment of cancer, of respiratory system diseases, and tackling the disparities in this area in the Malopolskie voivodship; 2 . Increasing the availability and quality of services in the field of prevention, diagnosis and treatment of diseases of the osteoarticular and muscular system, improving the availability and quality of services in the field of reducing the negative effects of injuries and defects significantly impairing the social or professional functioning of a human being, and tackling the disparities in this area in the Malopolskie voivodship. 3. Providing comprehensive and multilateral medical care as well as social and professional support to people with mental and behavioural disorders, which would be tailored to their needs. 4. Improving health care for mothers, newborns, and small children, as well as for the elderly, and tackling the disparities in this area in the Malopolskie voivodship. 5.. Increasing the availability and quality of services for chronically ill people, strengthening long-term care and development of community care, as well as tackling the disparities in this area in the Malopolskie voivodship. 6. Creating innovative solutions, increasing the availability of high-quality medical equipment, developing digital medical information and increasing the quality of e-services provided to patients, as well as tackling the disparities in this area in the Malopolskie voivodship and providing support for the medical staff education system in the context of adjusting resources to the changing social needs 
and tackling the disparities in this area in the Malopolskie voivodship ${ }^{18}$. These priorities are being implemented, inter alia, through the Municipal Healthcare Programme "Healthy Krakow 2019-2021" or the Krakow Development Strategy. I want to live here. Krakow 2030. "The Healthy Krakow 2019-2021" Programme is a continuation of the City Healthcare Programme "Healthy Krakow 2016-2018" and of earlier programmes. Three areas of activities are covered by this programme: the first one concerns the measures of Krakow residents' health; the second focuses on the healthcare resources in Krakow; and the last - the third area describes city's healthcare activities.

Implementation of the Municipal Healthcare Programme is to contribute to the achievement of one of the strategic objectives "Krakow - a friendly city to live in" and of the operational objective "The universal implementation of the idea of healthy and active life by providing city's residents with access to medical services under the health policy programmes, influencing the health-affecting factors and providing health education".

The most important programmes of the health policy for 2019-2021 include: The programme for preventing obesity, type- 2 diabetes, hypertension and atherosclerosis; the programme for ensuring equal access to healthcare in the place of education and upbringing in the City of Krakow; the programme for preventing the consequences of hip dysplasia; the programme for preventing caries in children; the programme for preventive vaccination against influenza after 65 years of age; the health programme for the prevention and detection of cardiovascular diseases in the population of the Malopolska voivodship; the programme for preventing meningococcal infections for children aged 12 to 24 months, residing in the Municipality of Krakow; the programme for preventing pneumococcal infections for children aged 03 years, residing in the Municipality of Krakow, attending crèches and kindergartens; the programme for preventing posture defects and the programme "Day Medical Care Centre" in the Municipality of Krakow.

Air quality is a problem that significantly affects the health of residents of the Malopolska Voivodship, in particular the Municipality of Krakow. For this reason, actions to improve air quality are carried out in accordance with the adopted policy, set out in the "Air Protection Programme for the Malopolska Voivodship".

In turn, the "Krakow Development Strategy. I want to live here. Krakow 2030" has been designed, inter alia, to handle issues related to sustainable development. Activities in this area are defined in the following programmes: Environmental Protection Programme for the City of Krakow; Low-Carbon Economy Plan for the Municipality of Krakow; Air Protection Programme for the Malopolska Voivodship; Environmental Protection Programme against Noise; District Forestry Increase Programme for the City of Krakow; Low-Carbon Reduction

\footnotetext{
${ }^{18}$ Priorytety dla regionalnej polityki zdrowotnej na okres od 1 stycznia 2019 r. do 31 grudnia 2021 r. Małopolski Urząd Wojewódzki w Krakowie [Priorities for Regional Health Policy for the Period from January 1, 2019 to December 31, 2021. Małopolska Voivodship Office in Krakow], BIP, https://bip.malopolska.pl/muw,a,1487284,priorytety-dla-regionalnej-polityki-zdrowotnej-na-okres-od-1-stycznia-2019-r-do-31-grudnia-2021-r.html (14.10.2021).
} 
Programme for the City of Krakow and Environmental Protection Programme against Electromagnetic Radiation ${ }^{19}$.

To conclude, it can be stated that despite the average life expectancy higher than for the whole country, the waiting time for specialists and hospital beds is exceptionally long. The analysis covering the medical facilities and access to treatment shows that the market of public medical services is not tailored to the needs of the inhabitants.

\section{CONCLUSIONS OF THE STUDY}

1. The rate of natural increase in Łódź Voivodeship is negative and amounts to 3.64 per 1,000 inhabitants. At the same time, in the Lesser Poland Voivodeship, with lower expenditure on medical treatment, more difficult access to physicians, and a smaller number of hospital beds, the rate of natural increase is positive and amounts to 1.6 per 1000 inhabitants.

2. The average age of inhabitants of Łódź Voivodeship is 43.3 years, which is slightly higher than the mean age of the general Polish population. Furthermore, the mean age in the Lesser Poland Voivodeship is 41.1 years, which is comparable to the mean age in the entire Poland. On the other hand, the mean life expectancy in the Lódź Voivodeship is 70.6 years for women and 79.8 years for men and is shorter than in the Lesser Poland Voivodeship, where the mean is 74.0 years for women and 81.9 years for men. It is worth noting that in the Lesser Poland Voivodeship, one has to wait exceptionally long for both a place in a hospital and an appointment with a specialist.

3. Expenditure on health care is also higher in the Łódź Voivodeship and amounts to over PLN 1600 per capita. Furthermore, in the Lesser Poland Voivodeship, this expenditure is PLN 1400- 1500 per capita.

4. There are about 25 physicians per 10,000 inhabitants in the Łódź Voivodeship while in the Lesser Poland Voivodeship this number was 23.

5. The number of hospital beds per 10,000 inhabitants is 51.2 in the Łódź Voivodeship and 44 in the Lesser Poland Voivodship.

6. Access to hospital care versus the incidence and mortality from diseases is as follows: for the Łódź Voivodship, the number of beds in cardiology wards is 3.1 per 10,000 inhabitants, with 372.20 deaths due to cardiovascular diseases per 100,000 inhabitants. At the same time, the number of cardiology beds in the Lesser Poland Voivodeship is 2.1 per 10,000 inhabitants and the number of death due to cardiovascular diseases was 331.40. As far as oncological diseases are concerned, the number of beds in the Łódź Voivodeship is 1.2 per 10,000 inhabitants and the mortality rate due to tumours is 202.30 per 100,000 inhabitants. In the Lesser Poland region, this number was 1.1 per 10,000 inhabitants and 185.90 per 100,000 inhabitants, respectively.

\footnotetext{
${ }^{19}$ Miejski Program Ochrony Zdrowia „,Zdrowy Kraków 2019-2021” [Municipal Healthcare Program “Healthy Krakow 2019-2021”], op.cit., (15.10.2021).
} 
Analysis of the data reveals that high expenditure on medical treatment, the highest number of physicians per capita, and relatively short time of waiting for an appointment with a specialist do not translate into the health status of the inhabitants of Łódź Voivodeship. The economic growth rate for the Łódź Voivodeship was lower than the national average and was only 2.8\%, whereas the gross domestic product in the Łódź Voivodeship in 2016 was $6 \%$ of Poland's GDP. A problem of Łódź Voivodship is a very low proportion of the population at pre-working age. In Poland, Łódź Voivodeship was ranked 14th. The mean gross salary in the enterprise sector is PLN 5397.98, and the unemployment rate in 2020 was 5.9\%. An additional problem is the excess mortality rate in residents at working age. The main causes of the high mortality rate in this group are diseases of affluence, such as cardiovascular disease or cancer.

Furthermore, the Lesser Poland Voivodeship, with its weaker medical infrastructure compared to the Łódź Voivodeship, has significant socioeconomic potential on the national scale. In 2018, the Lesser Poland region generated $8.1 \%$ of the country's GDP and, unlike the Lódź Voivodeship, is characterized by a high level of economic growth. The number of economically active people in the Lesser Poland Voivodeship is approx. 1.48 million, and the unemployment rate in 2020 was $4.4 \%$, lower than the national average (5.5\%). The mean gross monthly salary in the enterprise sector in the Lesser Poland Voivodeship was PLN 5308.73 (February 2020). For comparison, the mean gross monthly salary in the enterprise sector in Poland amounted to 5330.48 PLN.

Therefore, as public health specialists argue, life expectancy is influenced more by social conditions, lifestyles, diets, or unemployment rates than by medical infrastructure.

As early as 1973, M. Lalonde proposed the concept of 'health fields' and distinguished between the following four groups of health determinants:

- lifestyle (ca. 53\%): the set of decisions an individual makes that affects his or her health and that the individual can more or less control;

- physical environment (ca. 21\%): all its elements, external to the human body that an individual cannot control or can control to a very limited extent;

- human biology (ca. 16\%);

- organization of medical care (ca. 10\%): availability, quality, organization, type, and resources of medical care.

This concept led to the development of the socio-ecological model of health and the change in health policy in the world and laid the foundation for the development of health promotion. It also raised awareness of the role of lifestyles in shaping individual and collective health.

Therefore, the activities of public institutions in the field of pro-health policy aimed at improving public health are necessary. One example is e.g. the above presented EU programs for health prevention, which also perform educational and preventive functions, provide equal availability of benefits, improve their quality, and consequently, complete tasks related to the idea of sustainable development. 
The research conducted on the example of these two selected voivodeships confirms the assumption that the state of society's health influences the economic development of the country and at the same time makes a contribution to conducting the research on a larger scale.

\section{CONCLUSIONS}

Safety management in the area of health policy is being increasingly integrated into the EU's health and safety programmes. The European Union, together with the EU Member States, is pursuing a broad work programme in this area. In these programmes, EU policy also takes into account new challenges, such as improving public health, preventing and treating diseases, tackling pandemics, reducing the number of sources of danger to human health, reducing the inequalities in access to medical services, or harmonising health strategies between Member States. Therefore, the cooperation between Member States and the EU provides a platform for work on health inequalities and fundamental social determinants of health, the overall objective of which is to improve the health and well-being of EU citizens and, consequently, also to accelerate economic development. This joint action aims primarily to: identify a policy framework with a set of actions and recommendations for their adoption and implementation at national, regional, and local levels; develop better policies to improve monitoring, management, implementation, and evaluation; implement good practice and facilitate exchange and learning, as well as identify success factors, barriers and challenges, and ways to overcome them.

Health policy in the integrated health safety subsystem, implemented through comprehensive, purposeful, and organized actions of public authorities and supporting entities, constitutes one of the most significant forms of actions in the realization of the principles of sustainable development. Due to comprehensive, targeted, and structured action by public authorities and supporting entities, health policy is one of the most important forms of activity in implementing the principles of sustainable development. It should be borne in mind that the healthcare potential is strongly linked to the potential of the entire economy of a country or a region and that proper management of health policy determines health improvement and achievement of health and social well-being of a given population ${ }^{20}$.

That is why the definition of health policy priorities at the international, national or regional levels is an attempt to define more precisely the ways of action, their effects, including the performance measures in order to achieve specific operational objectives and ensure health benefits for the societies of individual countries. It is worth noting that all of these priorities are guided by one overarching, long-term strategic goal, which is to improve the health and related quality of life of the population. By setting out the directions for achieving the objectives, these priorities allow to expect that their implementation will result in many advantageous changes

\footnotetext{
${ }^{20}$ J. Hrynkiewicz (ed.), Mierniki i wskaźniki w systemie ochrony zdrowia [Measures and Indicators in the Health Care System], Warszawa 2001, p. 25.
} 
in the health of the population, including, for example, changes in the population's lifestyle, reduction of health inequalities and access to health services.

The implementation of health policy priorities contributes to increasing the institutional, collective and individual potential, which enables people to develop, improve or maintain their current quality of life as well as to function independently ${ }^{21}$.

\section{REFERENCES}

Akpolat Ahmet Gokce. 2014. "The Long-Term Impact of Human Capital Investment on GDP: A Panel Cointegrated Regression Analysis". Economics Research International: 1-10.

Auleytner Julian.2011. Polityka społeczna w Polsce i w świecie [Social Policy in Poland and in the World]. Warszawa: Wydawnictwo WSP TWP.

Bsoul-Kopowska Magdalena. 2019. Strategic goals of the European Union In managing health security. In R. Ulewicz, R.R. Nikolić (ed.). System safety: Human - Technical - Facility - Environment,78-84. Wydawnictwo De Gruyter.

Davies Norman.1999. Europa. Rozprawa historyka z historią [Europe: A History]. trans. E. Tabakowska. Kraków: Znak.

Dziadczyk Beata. 2006. Modele opieki zdrowotnej [Healthcare Models]. In M. Pierzchalska (ed.) Procesy globalizacyjne a myśl ekonomiczna Kościoła katolickiego [Globalization Processes and Economic Thought of the Catholic Church]. Wydawnictwo WSB.

Frąckiewicz Lucyna (ed.). 2002. Polityka społeczna. Zarys wykładu wybranych problemów [Social Policy. Outline of the Lecture of Selected Problems]. Katowice: Wydawnictwo Śląsk.

Gujski Mariusz (ed.). 2013. Zdrowie priorytetem politycznym państwa - analiza i rekomendacje [Health as a Political Priority of the State - Analysis and Recommendations]. Warszawa: Instytut Ochrony Zdrowia.

Liu Gorgon G., Dow William H., Fu Alex Z., Akin John, Lance Peter. 2008. "Income productivity in China: on the role of health". Journal of Health Economics 27: 27-44.

Hrynkiewicz Józefina (ed.). 2001. Mierniki i wskaźniki w systemie ochrony zdrowia [Measures and Indicators in the Health Care System]. Warszawa: Instytut Spraw Publicznych.

Ikeogu Dennis O., Uwakwe Joseph, Chidolue Ifeyinwa B. 2013. "The Effect of Health Safety Management in National Development". Mediterranean Journal of Social Sciences 4(7): 93-98.

Inac Husamettin, Guner Umit, Sarısoy Sisan. 2006. "Eğitimin Ekonomik Büyüme ve Kalkınma Üzerindeki Etkileri”. Eskisehir Osmangazi “Universitesi ‘IIBF Dergisi 1: 59-70.

Jack William, Lewis Maureen. 2009. "Health Investments and Economic Growth : Macroeconomic Evidence and Microeconomic Foundations". Policy Research working paper no. WPS 4877: 2-39.

Miejski Program Ochrony Zdrowia „Zdrowy Kraków 2019-2021”, Urząd Miasta Krakowa Biuro Ds. Ochrony Zdrowia Kraków 2018 [Municipal Healthcare Program "Healthy Krakow 2019-2021", Krakow City, Office for Health Protection, Krakow 2018], https://www.bip.krakow.pl > MPOZ_2019-2021 (11.10.2021).

\footnotetext{
${ }^{21}$ Z. Woźniak, W stronę zdrowia społeczności-socjologiczny kontekst nowej polityki zdrowotnej [Towards Community Health - The Sociological Context of New Health Policy], "Ruch prawniczy, socjologiczny i ekonomiczny" 2004 no. 2 , p. 181.
} 
Nowicka Paulina Maria, Kocik Janusz. 2018. „Zewnętrzne zagrożenia bezpieczeństwa zdrowotnego Polski [External Threats to Health Security of Poland]", Studia BAS 4(56): 103-121.

Ozt" urk Nazim. 2001. "İktisadi Kalkınmada Eğitimin Rolü” Sosyo Ekonomi Dergisi 1(1): 27-44.

Paruzel Robert. 2015. "Światowa Organizacja Zdrowia - bezpieczeństwo zdrowotne świata [World Health Organization - World Health Security]". Logistyka 5: 1207-1214.

Rabiega Agnieszka. 2009. Ochrona życia i zdrowia ludzkiego w działaniach podmiotów administrujących w sferze opieki zdrowotnej [Protection of Human Life and Health in the Activities of Administration Entities in the Field of Health Care]. Warszawa: Wydawnictwo Sejmowe.

Rudawska Iga. 2007. Opieka zdrowotna. Aspekty rynkowe i marketingowe [Healthcare. Market and Marketing Aspects]. Warszawa: Wydawnictwo Naukowe PWN.

Sytnik-Czetwertyński Janusz, Cianciara Dorota. 2016. "The individual face to face with public health: a conflict of interests or a conflict of conditions?". Journal of Education, Health and Sport 6(2): 223-237.

Szumlicz Tadeusz. 2004. System zabezpieczenia społecznego w zarządzaniu zdrowiem [Social Security System in Health Management]. In Zdrowie i jego ochrona. Między teorią a praktyką [Health and Its Protection. Between Theory and Practice], 83-95. Warszawa.

Taranowicz Iwona. 2010. Zdrowie i sposoby radzenia sobie z jego zagrożeniami. Analiza socjologiczna [Health and Ways of Dealing with Its Threats. Sociological Analysis]. Wrocław: Oficyna Wydawnicza Arboretum.

Weil David N.. 2005. "Accounting for the effect of health on economic growth." The Quarterly Journal of Economics 122(3):1265-1306.

Włodarczyk Cezary W. 2010. Wprowadzenie do polityki zdrowotnej [Introduction to Health Policy]. Warszawa: Wolters Kluwer Polska.

Woźniak Zbigniew. 2004. "W stronę zdrowia społeczności - socjologiczny kontekst nowej polityki zdrowotnej [Towards Community Health - The Sociological Context of New Health Policy]”. Ruch prawniczy, socjologiczny i ekonomiczny 2: 161-187.

Priorytety Dla Regionalnej Polityki Zdrowotnej Na Okres Od 1 stycznia 2019 r. do 31 grudnia 2021 r. Małopolski Urząd Wojewódzki w Krakowie [Priorities for the Regional Health Policy for the Period from January 1, 2019 to December 31, 2021. Małopolska Voivodship Office in Krakow]. BIP In https://www.bip.krakow.pl/_inc/rada/posiedzenia/show_pdfdoc.php?id=103632.

Strategia polityki zdrowotnej na lata 2014-2020. Zdrowie Łódzkie. Regionalny Serwis Informacyjny [Health Policy Strategy for 2014-2020. Lodz Health. Regional Information Service]. In https://zdrowie.lodzkie.pl/polityka-zdrowotna/strategia-polityki-zdrowotnej-nalata-2014-2020.

Zdrowie na rzecz wzrostu gospodarczego: Wspólnotowy program działań w dziedzinie zdrowia (2014-2020) [Health for Growth: Community Action Program in the Field of Health (20142020)]. In https://eur-lex.europa.eu/legal-content/PL/TXT/?uri=LEGISSUM\%3A290102_1).

Łódzkie: czy zdrowie będzie priorytetem samorządu w 2019? Polityka Zdrowotna [Łódź Voivodeship: Will Health Be a Priority for the Local Government in 2019? Health Policy]. In https://www.politykazdrowotna.com/40910,lodzkie-czy-zdrowie-bedzie-priorytetemsamorzadu-w-2019. 
Mapa zdrowia Polaków. Strategia Polityki Zdrowotnej Dla Województwa Łódzkiego na lata 2014-2020 [Health Map of Poles. Health Policy Strategy for the Lodz Voivodship for 2014-2020]. In http://www.strategiazdrowia.lodzkie.pl/files/file_16/STRATEGIAPOLITYKI-ZDROWOTNEJ-DLA-WOJEWODZTWA-LODZKIEGO-NA-LATA2014-2020.pdf.

Priorytety dla regionalnej polityki zdrowotnej dla województwa łódzkiego [Priorities for the Regional Health Policy for the Lodz Voivodship]. In https://www.lodzkie.eu/data/other/priorytety_dla_regionalnej_polityki_zdro_1.pdf.

Priorytety dla regionalnej polityki zdrowotnej na okres od 1 stycznia 2019 r. do 31 grudnia 2021 r. Małopolski Urząd Wojewódzki w Krakowie [Priorities for Regional Health Policy for the Period from January 1, 2019 to December 31, 2021. Małopolska Voivodship Office in Krakow]. BIP. In https://bip.malopolska.pl/muw,a,1487284,priorytety-dla-regionalnej-politykizdrowotnej-na-okres-od-1-stycznia-2019-r-do-31-grudnia-2021-r.html. 